\title{
Novice Teachers' Challenges and Survival: Where do Malaysian ESL Teachers Stand?
}

\author{
Fatiha Senom, Abd Razak Zakaria*, Shanina Sharatol Ahmad Shah \\ Faculty of Education, University of Malaya, Kuala Lumpur, Malaysia \\ *Corresponding author: abdrazak@um.edu.my
}

Received April 21, 2013; Revised May 01, 2013; Accepted May 11, 2013

\begin{abstract}
The transition from the teacher education institution to life in a real classroom has been characterized as a type of reality shock in which beginning teachers realize that the ideals they formed while training may not be appropriate for the realism they are faced with during their first year of teaching [1]. Unfortunately, this concern is not fully addressed in schools in Malaysia as beginning teachers have the same responsibility as a teacher with many years of service. It is suggested that it is not until they have survived the initial shock of the first year that novices are able to begin to concentrate on the important areas of long-term planning, overall student goals, and individual students' needs [2]. This article examines challenges that novice teachers in Malaysia face in their early experience of teaching through a review of significant literature. Based on recent studies from the literature, these challenges are discussed and future direction for research in this field is suggested.
\end{abstract}

Keywords: novice teacher, challenges, survival, teacher development, English as a Second Language (ESL)

\section{Introduction}

Novice teachers often do not feel adequately prepared for the challenges they face in their first years in the classroom. [3] note that "critics have long assailed teaching as an occupation that 'cannibalizes its young' and in which the initiation of new teachers is akin to a 'sink or swim,' 'trial by fire,' or 'boot camp' experience". Literature on the first year of teaching has been well documented in general education research, and it also has been recently established by language teacher educators as having a huge influence on the future development of language teachers. Nevertheless, not many in-depth studies elucidating the experiences of language teachers in their first year of teaching have been documented in the TESOL education literature [4]. The understanding on the experiences of teachers in their initial entry into teaching is essential as the early experience of teaching is a critical time for new teachers and may determine their philosophy and attitude teaching for the rest of their career [5].

\section{Novice Teachers in Malaysia}

Novice teachers experience an intricate transition from the teacher education institutions to life in real classroom. In spite of this, novice teachers in Malaysia do not receive adequate support, as there is no specific new teacher induction programmes to prepare them for the transition. Yet, new teachers assume the complete duties of a veteran teacher including the role as the head of panel of the subject [6]. In addition, many teacher professional development activities in Malaysia, which suppose to be potentially powerful supports in assisting novice teachers for the transition have often found to be as "pull out programmes", "one-shot programmes", "superficial", "fragmented", "quick fix", "disconnected", "episodic" and "lacking in follow-through" [7]. Not only that, they have also been argued to be inflexible, do not cater teachers' needs, time consuming and do not promote collaborative activities or provide supplementary support after the programmes.

Moreover, in a case study on English as a Second Language (ESL) teachers professional development in three primary schools in Malaysia, [5] argued that the prevalent form of professional development in the schools was unstructured and restricted in scope thus, failed to some extent to provide teachers with the relevant required professional skills and practice since ESL teachers. This is because, ESL teachers developed their teaching skills and competence merely through their initial education at teacher training colleges, an informal apprenticeship and years of teaching experience in the school besides relying on their past experience as students and by emulating their former teachers as role models. In addition, they learned about their professional roles and related skills intuitively by talking to colleagues and working with other teachers.

Furthermore, in the case study by [6] asserts that the only 'planned' approach to ESL teacher professional development was through in-service courses initiated by the Ministry of Education and its professional divisions. In-services courses required ESL teachers to leave schools for certain period to attend courses which were believed to enhance teachers' existing qualification, to assist teachers in areas which they perceived to be challenging, and to further enhance teachers' existing skills. Then, the ESL teachers were expected to share the information with their colleagues in the schools by conducting in-house training 
sessions, on returning to their respective schools. However, (6) argues that the in-house training sessions rarely occurred in the primary schools. According to [6], the inservice courses have the several limitations. This is because, some courses in his case study, were considered to be irrelevant, impractical and redundant thus there was a mismatch between the needs of teachers and the content of the courses. Additionally, courses were too theoretical and not applicable especially in the context of English as a foreign language. In addition, the role played by experts outside the school was emphasized thus teachers did not consider themselves or their colleagues as experts in their own school and consequently, mistrust among the teachers for internal teacher experts occurred. Likewise, only limited numbers of teachers were given the opportunity to attend those courses since the number of places available depended on the allocation of funds. [6] also argues that, the provision of the course was unsystematic and unplanned with providers determined choices thus, the locus control of teachers professional development still remained with the Ministry. He added that, the cascading model of in-service activities that encourage teachers to disseminate information received to colleagues through inhouse training was not implemented effectively due to time, work constraints and other priorities.

With inadequate support, it is more likely that the experiences novices encounter upon their transition will result in creative and talented teachers finding their work frustrating, unrewarding and intolerably difficult which ultimately increases their risk of becoming a casualty of the profession [8]. This is also because, problems faced by the novice teachers will not be solved simply through the growth of their teaching experience [9]. The lack of emphasis given on the novice teachers' transition is perhaps due to minimal understanding on challenges that the beginning teachers face in their first years of teaching. While the research literature on newly qualified teachers is growing, we do not yet know enough about challenges that novice teachers face in the Malaysian context since research on novice teacher is scarce in Malaysia [10]. Therefore, there is a need to explore the experience of ESL novice teachers in Malaysia by understanding the challenges they faced in their first years of practice, what is more, the early experiences are powerful influences on teachers' practices and attitudes throughout the remainder of their careers [5].

\section{Methodology}

There is a substantial body of educational research into novice teachers and challenges they face in the first years of teaching. In this article, literature on the first years of teaching experience of ESL novice teachers in Malaysian are examined. The local literature were reviewed and juxtaposed with significant scholarships about early teaching experience of novice teachers in other countries. Academic databases such as Web of Knowledge, ProQuest and JSTOR were used to obtain eighteen related literature [1,4,11-26] and these include five local studies [22,23,24,25,26] about novice teachers in Malaysia. This article proceeds in three sections. First, the scholarships on novice teacher's experiences, problem and challenges are reviewed. Second, literature on challenges of Malaysian
ESL novice teachers are examined. The third section draws together the first two in arguing for a shift in discourse and focus, in both research and practice, for the development of ESL novice teachers in Malaysia. This article concludes by considering implications for practice and future research possibilities on understanding of novice teachers.

\section{Section 1: Scholarships on Novice Teachers' Experiences, Problems and Challenges}

The [11] meta-analysis study is a classic text in the area of novice teacher problems. Drawing upon studies that had been conducted from 1960 until 1983, the study analysed 83 studies on the problems of beginning teachers. The study listed out 24 problems of beginning teacher that were cited most frequently in the studies he examined. Classroom management, student motivation, handling differences among students, grading student work and dealing with students' parents are the five most commonly reported problems that novice teachers face in the cited studies. In addition, [11] argues that, beginning teachers struggle with problems pertaining to dealing with problems of individual students, heavy teaching load with little preparation time, relations with colleagues, planning of lessons and schooldays, effective use of different teaching methods, awareness of school policies and rules, determining learning level of students, and knowledge of subject matter. The remaining problems include; burden of clerical work, relations with principals/administrators, inadequate school equipment, dealing with slow learners, dealing with students of different cultures and deprived backgrounds, effective use of textbooks and curriculum guides, lack of spare time, inadequate guidance and support, and large class size. [11] also argues that it is a common concern for beginning teachers to feel that they have limited knowledge on the subject matter they were teaching. He also describes the transition for beginning teachers from teacher training to the first teaching job as both dramatic and traumatic. He also refers to the transition as a reality shock that occurs when novice teachers' ideals formed during pre-service training are collapsed by the harsh realities of every day classroom life.

The study by [12] reviews studies on novice teacher concerns to ascertain if teachers in particular subject areas had special problem. It is found that the majority of the cited research on the concerns of beginning teachers has some common findings despite of differences in the research methods or the sample of participants. The review recognises the 12 most common concerns of beginning teachers which include managing the classroom, acquiring information about the school system, obtaining instructional materials and resources, planning, organizing, and managing both instruction as well as other professional responsibilities, assessing students and evaluating student progress and motivating students. Whilst acknowledging the common concerns of beginning teachers, the study by [12] also found other significant concerns on using effective teaching methods, dealing with individual students' needs interests, abilities, and problems, communicating with colleagues, including 
administrators, supervisors, other teachers, communicating with parents, adjusting to the teaching environment and role, and emotional support.

Conversely, recent studies on novice teachers concerns, problems and challenges indicate new challenges emerge. For instance, the [13] qualitative multi-case study on three novice teachers from diverse backgrounds and different preparation programmes who teach in kindergarten and elementary school in New Mexico illustrates that new problems such as inadequate or irrelevant pre-service preparation and difficult first-year teaching assignments to be among the common struggles that the novice teachers have to deal with besides other common struggle such as lack of adequate materials and resources, nonteaching responsibilities and reality shock. On the other hand, lack of personal support (from friends and family), financial difficulties, isolation, overwork and fatigue, as well as deficit thinking is listed to be unique struggles of the participants in the first year of teaching. The study also found that factors such as lack of specific curriculum guidelines, collegial planning, mentoring support, administrative supervision and time to "do it all", to contribute to the participants' struggles in the first year. The findings from the study suggest that novice teachers struggle during their first year of teaching regardless of the way in which they were prepared, previous life experiences and differing school and classroom contexts. The findings also imply that new teachers lack systematic and appropriate support necessary to mitigate the difficulties and challenges of the first year. The study suggests that programs to support new teacher during their first year should address contextual issues, especially isolation from colleagues and the lack of specific, relevant feedback regarding teaching performance.

Similarly, new problem emerges in [14] case study of four first year teachers in two urban elementary schools in Central Texas. The individual and cross-case analyses of the study indicate additional component to the lists of perceived problems of beginning teachers by $[11,12]$. This is because, the findings of the study by [14] implies that the participants also encountered challenges in understanding the cultures of their students and working with English language learners. These difficulties are due to the context of the schools that are located in urban districts which tend to be large with the rich diversity of communities within the district. Higdon argues some recommendations to overcome these challenges that requires active participation from school administrators especially from the principals of the schools. On the other hand, findings from [15] case study imply that fatigue and illness to be among the challenges for the participants in the study. This study examined the life of two new elementary teachers during their first year in the profession and also found time management and new professional roles to be major challenges for the participants. The study by [15] suggests that an induction programme could be developed to avoid challenging areas and provide beneficial items that were associated with a solid beginning in the profession. Similar to [14] study, the study by [15] concluded that the building principal and the district induction programme director need to be actively involved in the organization and on-going implementation of first year induction activities and assessments in order to enhance the outcomes of the initial professional development experience.

In a larger scale study by [16] that involves Ontario graduates from a two year pre-service program, 86 novice teachers were surveyed. The findings of the research indicate that hiring practices and meeting special needs are rated as the most challenging for the new teachers. Additionally, the amount of classroom resources, individual education plan and English language learners to be challenging. Survey data also revealed that the new teacher in the study also found that classroom management, salary and wages, balanced literacy, longrange planning, communication with parents, and communication with administration to be significantly challenging. Participants in the study [16] study also recognized administrative leadership, refining the mentorship selection process, hiring practices and districtsponsored supports as the positive factors that are essential for them to grow into the profession. In the [17] three-year longitudinal study that investigates the successes and challenges that elementary teachers in Ontario, Canada face in implementing literacy programmes, participants reported a number of factors as inhibiting to their successes within the classroom. This include: lack of agency and support (administrative and/ or home), continuity in staffing, position assignment, school initiatives, and programme usage, policies and procedures for governing school operations. Moreover, participants in the study face challenges such as professionally demanding and unclear job assignment, poorly trained resource staff, inappropriate scheduling of resource support, classroom management issues, discrepancies between academic demands and theoretical understandings, language barriers in ESL teaching and learning and, health problems tied to stress, overwork and/or school or parent demands. Nevertheless, the participants identify factors such as sufficient 'vision' from the pre-service education programme, accumulation of experience in the classroom as well as increased familiarity with language arts content and expectations with their students, contribute to the success in designing and implementing effective literacy programmes. Likewise, participants also suggest significant factors such as social and academic growth of their students, supportive community and school setting, availability of resources and extra professional training, including the existence of formal mentorship programs and connection to previous experiences as well as training and beliefs to have similar impact on the effectiveness of implemented literacy programmes.

The study by [18] discovers how first-year teachers reframed their initial challenges as they reflected on their teaching experience. Using qualitative approach, three Professional Development School programme graduates teaching in different elementary Professional Development Schools in a Mid-Atlantic metropolitan area were interviewed. Participants' initial challenges pivot around four themes: curriculum, meeting student needs, teaching practice, and workload. Challenges of curriculum includes its amount, curriculum planning, and integration of the curriculum while challenges of meeting students needs include diagnosing their needs and meeting needs of individual students. On the other hand, challenges in practice comprise issues such as sickness and injury that 
interfere with practice, need for independence, living up to own expectations, conflicts, classroom management, team teaching, and need for appropriate support. Whereas, challenges with workload take account of unexpected amount of workload and administrative tasks, time required doing a good job and schooling pressure. Findings from this study suggest that the participants were able to learn from experience and reframe their initial challenges as they had a clear vision about their responsibility in creating and maintaining an optimal teaching and learning environment based on pre-service training and experience. They also had a reflective partner at the school that shared a similar vision and school environment that was receptive to change and allowed them the freedom to examine and transform their teaching practice, and these enable them to learn from experience and reframe their initial challenges.

In addition, the study by [19] investigates the types of problems experienced by novice teachers who were recent graduates of a teacher preparation program in various fields in Northeastern states, US. Using survey methodology, the results of the study suggest that teacher problems can be grouped into 6 categories, teaching, personal matters, outside testing, bureaucracy, colleagues, and resources. The largest numbers of teacher problems come under teaching and personal matter categories. Respondents in the study also reported that teachers' problems related to teaching and colleagues to be most bothersome and occur most frequently. This include problems such as motivating students, being fair, supportive and honest with students and their parents, having unmet classroom expectation, student behaviour and classroom management, addressing individual student learning needs, dealing with parents, communicating with colleagues, working together, and school politics. Problems in these categories also are reported to have least tendency to be solved as compared to problems in other categories. To resolve problems, respondents in [19] opt for various sources including talking to colleagues, taking time to relax and altering their lessons.

The current landscape of the teaching enterprise sees the integration of ICT into teaching as a challenge for novice teachers. In the school context of the participant in the study by [20], teachers in upper secondary schools in Bergen, Norway are required to completely integrate ICT into teaching since all students have their own laptop with access to the Internet. Consequently, this challenges the teachers as they need to communicate with students using e-mail beyond school hours in order to successfully teach in fully digital environment. As a result, the participants of this study find it difficult to balance up between professional duties and having private life after school. Using semi-structured interviews, the nine novice teachers in the study also stated that challenges at personal level require them to spend a large amount of time and energy on the job and this forced them to put aside their family and personal life. Besides, they also feel that there is no time for reflection and they often uncertain of the quality of their work since very little feedback is given on their work. In addition, challenges pertaining to the students and the community such as the demanding expectation for novice teachers to be as good as experienced teachers are also reported in the study. In spite of that, the findings of the study also suggest the positive aspects of being a new teacher as the participants in the study express common positive opinions such as they enjoy teaching and they receive some support. They also committed to their work and value teacher education as a foundation for their teaching carrier.

Even though the first year of teaching has been well documented in general education research, and even recently has been established as having huge influence on the future development of language teachers by language teacher educators, not many thorough studies illustrating the experiences of language teachers in their first year of teaching have been documented in the Teaching of English to Speakers of Other Languages (TESOL) education literature [4]. One of the studies that take into account TESOL context is the study by [1]. This case study discusses the challenges and forms of personal influences of one beginning teacher through during his first year as an English language teacher in Singapore. The study also documents the teacher's experience as he was socialized through different stages of development as accordance with reference to [21] five stages of teacher development of beginning teachers. The findings indicate that the participant struggle with "reality shock" as his teaching load greatly increased from what he had experience in his practicum. He also faced two major dilemmas specifically the setting and marking of examination papers and his relationship with lower English proficiency students. The participant also found that the school in which he is teaching exhibit the culture of individualism and as a result, he received inadequate support and there is lack of communication with his colleague which hinders the opportunity of sharing and collaborating. In terms of stages of development, he first enter the school with early idealism, followed by survival stage where he sought quick fixes for discipline problem he was facing in the class he was teaching as [21]. However, he continually moving back and forth between final three phases: recognizing difficulties, reaching a plateau, and moving on. He then began to focus on the quality of his students' learning toward the end of the first year.

Later in [4] the participant's complications during his first year are discussed thoroughly and categorized into three major themes; teaching approach, course content and collegial relationships. Teaching approach complications take place when the participant has to reconcile the differences between his beliefs in effective teaching approach than the approach existed in school. The participant strongly believes that students-centred approach contributes to more effective learning than teacher-centred approach, however, he found it difficult to establish student-centred approach since school regulation that do not tolerate noise level, pupil movement and control of the class. The participant also struggle with course content complication as he encountered a conflict between what he wanted to teach and what the department required him to teach. He also feel that his creativity is restricted by the course content required by the department that he must comply with and this is also due to rigorous examination system. He also faces collegial relationship complication as he was left on his own throughout the year. He also experiences a great difficulty understanding the general culture of the school and the decisions made by English department. 


\section{Section 2: Malaysian ESL Novice Teachers: Challenges \& Survival}

While the research literature on newly qualified teachers is growing, we do not yet know enough about challenges that ESL novice teachers face in the Malaysian context since research on novice teacher is scarce in Malaysia [10]. However, a nationwide large-scale study [22] on the readiness of novice teachers' professionalism provide some general picture on the challenges that novice teachers from various fields faced during their first years. The survey of the study reveals that, the 910 respondents report that they were facing moderate amount of problems pertaining to curriculum specifications, resources, teaching preparation, classroom teaching, classroom management, interpersonal relationship, assessment and evaluation, school, administration and service policies, and co-curriculum. An in depth examination of this data found that the novice teachers participating in the survey of the study rate students' low English proficiency as the most frequent problem they face during their first years of teaching.

The nationwide large-scale study [22] also employed structured interviews to explore novice teachers' socialization experience. Four participants were interviewed, and data on the socialization problems faced by the novice teachers were categorized into four groups namely: problems concerning students, school community, teaching profession and parents. The novice teachers in the study informed that among the problems concerning the students include lack of interest in learning, illiteracy, misbehaviours and lack of discipline and negative attitude towards learning English. In terms of problems concerning the school community, the novice teachers in the study reported that they were struggling with burden of teaching assignments and clerical works, new leadership roles, high expectation, lack of support and guidance, isolation and school politics. Furthermore, the novice teachers noted that among the problems concerning teaching profession they faced include, inadequate and irrelevant teaching preparation course, fatigue, time consuming and tedious teaching preparation and lesson planning as well as difficulty in applying theory to practice. The novice teachers also found that they were struggling with high expectations from the parents. Despite of the struggles, the novice teachers in the interview consider the challenges to be valuable experience in which they can learn from. They found that positive and rewarding factors such as genuine interest in becoming a teacher, students' good performance and interest in learning as well as supports and guidance from colleagues and school administrators, motivate them to remain in the profession and continue learning to be effective teachers.

There are also few studies conducted in Malaysia that investigate the challenges that ESL pre-service teachers face during teaching practice and these studies are also able to give some illustration on the challenges that ESL novice teachers in Malaysia face in their first year of teaching. As for example, [23] identify five challenges that burden the ELT pre-service teachers in primary schools which are supervision, environment, workload, pedagogical knowledge and context knowledge. [23] also discover that, despite of having many positive aspects of teaching practice among the participants of the study, almost $55 \%$ of the pre-service teachers find that their teaching practice failed to give them the opportunities to engage in theory and practice as they are overwhelmed by the realities of the classroom. Although the five challenges are discussed in [23], the strategies adopted by the participants in the study to overcome the challenges are not investigated. This implies the possibility that the preservice teachers in the study may not be given the opportunity to reflect upon how they overcome the challenges faced during their teaching practice.

Similarly, [24] conducted a case study on the challenges faced and the strategies adopted by a female English language teacher during teaching practice. The participant of the case study was placed in a sub-urban secondary school and she was asked to write a reflective report in which she had to identify three major challenges faced during her teaching practice as well as the strategies adopted to meet those three challenges. She was then required to submit the reflected report at the end of the teaching practice, which lasted for almost three months. A series of interviews were then conducted to crosscheck the reliability and validity of the contents of the reflective report. The findings of the study found the three main challenges of the participants during her teaching practice are students' mixed-ability, the use of mother tongue and expectations of teacher-centeredness. The study also discovered that the participant use the strategies which draw upon participant's effective pedagogical knowledge and practices to overcome the challenges and these include; using previous teaching and learning experience, experimenting through trial and error of theories and ideas, understanding the challenges, being determined, persistent and perseverant, compromising and finding a "middle ground" and encouraging, prompting and motivating.

On the contrary, the study by [25] examines the similar challenges but involving 38 ESL trainee teacher who are mostly from China during their practicum in local secondary schools in Malaysia. Based on the findings, the main challenges faced by their trainee teachers were the cultural differences, applying from theory to practice especially on appropriate teaching methodology or strategy, students' discipline as well as the relationship with mentors and supervisors. The discussion of the study also revealed that the trainee teacher struggle with mixed ability classroom as they found it difficult to teach the students according to their ability and proficiency and due to students' low proficiency, trainee teachers also faced language barriers, as the students prefer to communicate only in their mother tongue. These findings are congruent with the findings from the study by [24] where mixed ability students and the use of mother tongue during English lesson as among the challenges faced by preservice teachers. Despite of these challenges, the participants in [25] study indicated positive comments regarding supports, guidance and cooperation they received from the school administrators, their mentors and their supervisors.

In a recent study by [26], the Malaysian English teachers' concerns on the implementation of the schoolbased assessment were investigated. The study was conducted in response to the shift in assessment system for Malaysian public school. The newly implemented assessment approach aims to promote a combination of 
centralized and school-based assessment to replace the previous fully centralized assessment. The school based assessment system was implemented in 2010 and teachers are given empowerment in assessing their students. Nevertheless, school-based assessment requires teachers to have adequate knowledge and skill in employing various informal methods of testing and psychometric testing. A total of forty English teachers who were teachers with range 5 months to 21 years of teaching experience from various Malaysian public secondary schools took part as respondents in [26] study. The findings of the study indicate that, new teachers with less than 5 years of teaching experience were uncertain about the school-based assessment requirements. The new teachers in the study were not confident about their ability to administer school-based assessment and they were unclear about their roles as teachers. In addition, they faced difficulty in getting students understand the roles of students in school-based assessment besides expressing their concerns on the possible negative impacts the assessment would have on their students. The findings of the study also suggest that due to lack of understanding and training on school-based assessment, the participating novice teachers demanded for essential changes to the newly implemented school-based assessment system. Therefore, [26] suggest for in-service trainings to be conducted for the novice teachers to acquire knowledge and skills on school-based assessment. In addition, it is also suggested for more practical approaches such as workshops and open discussions on the challenges and issues in implementing the assessment to be carried out to provide relevant information to the Ministry in order to decide on the required modifications to the current assessment's policies and guidelines.

\section{Section 3: Arguing for a Paradigm Shift in Novice Teacher Development}

Although there are rich literatures on novice teachers' challenges in their first years of teaching, due to the small sample size and distinctiveness of the context, the ability for most of the reviewed research to generalize their findings into Malaysia context is limited. On the other hand, while the nationwide large-scale study [22] provide some general picture on the challenges that novice teachers from various fields faced during their first years, the study takes into account novice teachers from various disciplines thus, it does not describe precisely the challenges of ESL novice teachers in their first years of teaching English in Malaysia. Conversely, studies by $[23,24,25]$ focus on ESL pre-service teachers rather than ESL novice teachers, and there are great differences between both groups as novice teachers have more teaching loads, professional responsibilities and given higher expectations as compared to ESL pre-service teachers who teach only in short duration of time during teaching practice. Therefore, there is a need to fill the existing gap in the current research by scrutinizing the challenges the ESL novice teachers face during their first years of teaching English in primary schools Malaysia. The understanding of novice teachers challenges make it possible to ascertain how new teachers require support so that schools, administrators, district boards, the ministry of education and all the stakeholder can effectively support the success of newcomers to the profession.

In addition, due the employment of the traditional definition of teachers professional development which consider the development as something that is done by others for or to teachers, workshops, seminars, courses and conference become predominant forms of professional development practices available in Malaysia. In contrast, recent trends of teacher professional development in other countries such as the United Kingdom, United States, Australia and Japan, highlight on alternative professional development structures that provide teachers the platform for self-directed, collaborative, inquiry-based learning that is directly relevant to teachers' classroom which recognizes teachers' informal social and professional networks, including their own classroom as powerful sites for professional learning [27]. These alternative structures include teacher inquiry seminars, peer coaching, cooperative development, teacher study groups, narrative inquiry, lesson study groups, and critical friends groups. Such alternative structure encourage teachers to engage in on-going, in-depth, and reflective examinations of their teaching practices and their students' learning by recognizing the critical role that context plays in teacher learning and L2 teaching [28] while embracing the processes of teacher socialization that occurs in classroom, schools, and the wider professional communities where teachers work.

\section{Conclusion}

Therefore, in order to ensure ESL teaching in Malaysia to benefit from more effective structures of teacher professional development, there is a need for educational environment in Malaysia to pursue the current trend of more self-directed, collaborative and inquiry-based approach of professional development programmes as well. Besides, the adoption of these alternative structures will address the importance of more individual oriented notion of professionalism as a crucial part to the prevailing forms of teacher professional development programmes in Malaysia, which generally pivot around institutionally endorsed and publicly heralded definition of professionalism [29].

\section{References}

[1] Farrell, T.S.C. (2003). Learning to teach English language during the first year: personal influences and challenges. Teaching and Teacher Education, 19, 95-111.

[2] Marshall, P., Fittinghoff, S., \& Cheney, C. (1990). Beginning teacher developmental stages: implications for creating collaborative internship programs. Teacher Education Quarterly 25-35.

[3] Smith, T. M., \& Ingersoll, R. M. (2004). What are the effects of induction and mentoring on beginning teacher turnover? American Educational Research Journal, 41(3), 681-714.

[4] Farrell (2006). The first year of language teaching: imposing order. System, 34, 211-221.

[5] Kuzmic, J. (1993). A beginning teacher's search for meaning: Teacher socialization, organizational literacy, and empowerment. Teaching and Teacher Education, 10, 15-27.

[6] Ali, M. S., (2002). Professional development of ESL teachers in primary schools. TIGAENF Jurnal Pendidikan IPBA, 2(5), 43-62.

[7] Lim, Tina Swee Kim and Zoraini Wati , Abas (2010) Online Inservice Teacher Professional Development in Malaysia: A New 
Possibility? In: Global Learn Asia Pacific (Global Learn) 2010, 17 May 2010, Penang, Malaysia.

[8] Fantilli, R.D., \& McDougall, D. E. (2009) A study of novice teacher: challenges and supports in the first years. Teaching and Teacher Education, 25, 814-825.

[9] Tsui, A. B. M. (2003). Understanding expertise in teaching. New York: Cambridge University Press.

[10] Hj Othman, N., Mohamod, Z., \&. Ibrahim, M. S. (2008). Profesional Guru Novis: Model Latihan. Terbitan Fakulti Pendidikan, Universiti Kebangsaan Malaysia.

[11] Veenman, S. (1984). Perceived problems of beginning teachers. Review of Educational Research, 54, 143-17.

[12] Gordon, S. P. (1991). How to help beginning teachers succeed. Alexandria, VA: Association for Supervision and Curriculum Development.

[13] Carpenter, J.L. (2002). Struggles, strategies, settlements and survival: Case studies of three beginning teachers. (Doctoral dissertation). Retrieved from ProQuest Dissertations and Theses database. (UMI Number:3072241).

[14] Higdon, K.A., (2005). First-year teachers in unfamiliar territory: case studies of novice teachers in urban schools. (Doctoral dissertation). Retrieved from ProQuest Dissertations and Theses database.

[15] Eckola, J. H., (2007). A case study: the benefits and challenges of first year teacher induction as perceived by two first year teacher. (Doctoral dissertation). Retrieved from ProQuest Dissertations and Theses database. (UMI Number:3259717).

[16] Fantilli, R.D., (2009). A study of novice teachers: challenges and supports in the first years. (Doctoral dissertation). Retrieved from ProQuest Dissertations and Theses database.

[17] Leslie, L.E., (2010). Becoming a literacy teacher: from teacher preparation through the first two years of literacy teaching. (Doctoral dissertation).Retrieved from ProQuest Dissertations and Theses database.

[18] Souder, K. O., (2005). Reframing initial challenges through collaborative reflection: a study of first year teachers in a professional development school. (Doctoral dissertation).
Retrieved from ProQuest Dissertations and Theses database. (UMI Number: 3163739)

[19] Pfister. C.C., (2006). Problems of beginning teachers at the secondary level. (Doctoral dissertation).Retrieved from ProQuest Dissertations and Theses database. (UMI Number: 3241865).

[20] Ulvik, M., Smith, K., \& Helleve, I., (2009). Novice in secondary school- the coin has two sides. Teaching and teacher education. 25 835-842.

[21] Maynard, T., Furlong, (1995). Learning to teach and models of mentoring. In: Kelly, T., Mayes, A. (Eds.), Issues in mentoring. London: Routledge.

[22] Ministry of Higher Education \& Ministry of Education (2006). Professionalism readiness of novice teachers: suggested training module, Penerbitan Fakulti Pendidikan. UKM.

[23] Ong, S.K., Shabudin, R. A., Azlian, A. A., Shanti, K \& Ho, L. C. (2004). Trainee teachers' perceptions of the school practicum. Proceedings of the National Seminar on English Language Teaching 2004. Bangi: Faculty of Education. Pp. 84-9.

[24] Kabilan, M.K., \& Raja Izzaham, R I., (2008).Challenges faced and the strategies adopted by a Malaysian English Language teacher during teaching practice. English Language Teaching. 1 (1), 87-95.

[25] Md Yunus, M., Hashim, H., Mohd Ishak, N., and Mahamod, Z. (2010). Understanding TESL preservice teachers' teaching experiences and challenges via post practicum reflection forms. Procedia Social and Behavioral Sciences, 9, 722-728.

[26] Majid, F.A., (2011). School-based assessment in Malaysia Schools the concerns of the English teachers. Journal of US-China Education Review, 8 (10), 393-402.

[27] Johnson, K.E. (2009). Trends in second language teacher education. In Burns, A., \& Richards, J. C. (Eds.). (2009). The Cambridge guide to second language teacher education. Cambridge: Cambridge University Press.

[28] Rogers, C. (2002). Seeing student learning: teacher change and the role of reflection. Harvard Educational Review, 72, 230-253.

[29] Leung, C. (2009). Second language teacher professionalism. In A. Burns \& J. C. Richards (Eds.), The Cambridge guide to second language teacher education (pp. 49-58). Cambridge: Cambridge University Press. 